\title{
Archaeologia
}

http://journals.cambridge.org/ACH

Additional services for Archaeologia:

Email alerts: Click here

Subscriptions: $\underline{\text { Click here }}$

Commercial reprints: $\underline{\text { Click here }}$

Terms of use : $\underline{\text { Click here }}$

\section{XVI.-On certain Inaccuracies in the ordinary Accounts of the early years of the Reign of King Edward IV}

Charles Spencer Perceval

Archaeologia / Volume 47 / Issue 02 / January 1883, pp 265 - 294

DOI: 10.1017/S0261340900004938, Published online: 25 January 2012

Link to this article: http://journals.cambridge.org/abstract S0261340900004938

How to cite this article:

Charles Spencer Perceval (1883). XVI._-On certain Inaccuracies in the ordinary Accounts of the early years of the Reign of King Edward IV. Archaeologia, 47, pp 265-294 doi:10.1017/S0261340900004938

Request Permissions : $\underline{\text { Click here }}$ 
XVI.-On certain Inaccuracies in the ordinary Accounts of the early years of the Reign of King Edward IV. Communicated by Charles SPEncer Perceval, Esq. LL.D. Treasurer.

Read February 17, 1881.

Having lately had occasion to examine with some particularity the sequence of domestic events during the first four years of King Edward the Fourth, especially in connection with the movements, during part of that time, of the deposed King Henry and his consort, Margaret of Anjou, it has surprised me to find how confusedly the period in question has been treated. ${ }^{a}$

I found it difficult, at first, to believe that by several of the chroniclers, historians, and peerage-writers, an event of primary importance, the battle of Hexham, which for practical purposes gave the coup de grace to the Lancastrian dynasty, has been antedated by a whole year.

This glaring chronological error, and certain mistakes or misapprehensions dependent on it, have never, so far as I can ascertain, been completely pointed out and corrected by any modern historian, however correct his own chronology may have been.

Yet, considering that the chronicles of Halle, Grafton, and Holinshed, the principal authors of the confusion which I notice, are still frequently referred to, and that their errors have been followed in more than one popular English

a The expressions used by Sir Henry Ellis (Original Letters, 2nd S. i. 94) writing 57 years ago are nearly as applicable now as then. "This erentful period," says he, "though removed from us scarcely more than three centuries, is still among the darkest on our annals. Its records are confused, mutilated, and disjointed. They who wrote history in it had no talents for the task; and there was a ferocity abroad among the partizans of both the rival houses, which prevented many from even assembling the materials of history."

It is from Mr. Halliwell Phillipps's introduction to Warliworth's Chronicle, edited by him for the Camden Society in 1839, that I borrow this quotation. This was, perhaps, the most valuable contribution to the knowledge of the period which had appeared since Ellis wrote, and was calculated to raise great hopes, since well justified, of the utility of the labours to be performed by the Society then in its infancy.

VOL. XLVII. 
history, it certainly seems worth while to point out and correct their mistakes; and it is this task which I have endeavoured to accomplish in the present paper.

Here I may observe that, of all the English historians whose works I have consulted, Sharon Turner appears (in respect of the period in question) to be by far the most accurate. Lingard, usually so careful, has made a curious slip in his dates which, though very easily corrected, cannot fail to mislead a student seeking in his pages for exact information. The only book to which $I$ have turned, and which I find unimpeachably correct, though the matter is necessarily much condensed, is Mr. James Gairdner's little work, entitled The Houses of Lancaster and York, London, 1875.

In order to render my purposed criticism more readily intelligible, I have thought it necessary to compile, from what appear to be the best, and as far as possible contemporary, sources, the following summary of the events of the years 1461 to $1465 .{ }^{a}$ This I have endeavoured to do as succinctly as possible, stating the mere leading facts wherever I have found no dispute or discrepancy to exist, but expanding the narrative where contradictions occur, and examining into their origin. The wish to increase the interest of a dry historical resumé must be my excuse for certain slight digressions, not strictly necessary to my immediate purpose, but introducing a little new matter (chiefly from two very recent publications of the Camden Society), which has not yet found its way into our general histories.

Proclamation of K. Edw. IV. March 4, 1461

Battles of Ferrybridge and Towton, March, 1461.
On March 4, 1461, Edward Earl of March was proclaimed king by the style of King Edward IV. His regnal year therefore begins, be it remembered, on March 4 in every subsequent year.

On the 27th and 28th of the same month were fought the battles of Ferrybridge and Towton, villages a few miles south of York. In the latter of these

a Subjoined are the titles and editions of the works to which I shall chiefly refer, with the abbreviations used in citing them.

William Wyrcestre or Worcester, cited as "Wyre," from Hearne's edition at the end of the second volume of Liber Niger Scaccarii, 2nd ed. London, 1771. Warkworth's Chronicle of the First Thirteen Years of King Edward IV., ed. Halliwell (Camden Society) 1839. William Gregory's Chronicle of London, ed. Gairdner (Camden Society), 1877, cited as "Gregory." A Brief Latin Chronicle, ed. Gairdner, in Three Fifteenth Century Chronicles, (Camden Society) 1880; and Brief Notes, an historical compilation in the same volume. The last three chronicles give several new facts and are otherwise very valuable. Fabyan's Chronicle, ed. 1533, cited as "Fabyan." A Fragment of a Chronicle relating to King Edward IV. printed by Hearne at the end of Sprott's Chronicle, 1719, cited as "Hearne's Fragment." Halle's Union of York and Lancaster, 1548. Grafton's Chronicle, 1568. 
engagements King Henry VI.'s troops were entirely worsted, and he, with his consort and Prince Edward, their son, fled into Scotland, where they were hospitably received by the Court.

It is not clear what strong places north of York there were at this time armed and manned by Henry's partisans. The important border fortress of Berwick-on-Tweed, we know, held out for him, for, as the price of assistance from the Scots, he surrendered this place to them. ${ }^{n}$

He himself seems to have collected about the same time a force of some sort, Scots perhaps and Borderers, and to have got as far south again as Ryton and Brancepath, in Durham, ${ }^{\text {b }}$ and indeed to have penetrated into Yorkshire, for, if we can trust Thomas Playter writing to John Paston on April 18, 1461, Henry was then besieged at a place in that county which he calls "Coroumbr, such a name it hath or muche lyke," the Queen and Prince Edward being reported to be with him.

The Scots, in consideration it appears of the surrender of Berwick, made an expedition against Carlisle, but, in June, 1461, the siege was raised by John Lord Montagu, brother to the "King-maker," the Scots losing on this occasion, according to contemporary rumour, 6000 men. ${ }^{d}$

Henry in his abortive expedition appears to have incurred great risk of capture, but to have got away, probably back to Scotland, to which country Margaret certainly retired.

She appcars to have remained there until April, 1462. In that month she sailed from Kirkcudbright, passed down St. George's Channel, and landed in Brittany, on or about Good Friday, April 16. According to William Wyrcestre, whose contemporaneous notes are most valuable for the elucidation of the events of this period, she first went to her father in Anjou. ${ }^{\circ}$ The object of her journey was to obtain assistance in her project of an invasion of England.

Louis XI., first cousin to herself and to Henry, had very lately succeeded to the crown of France, and to his court she bent her steps.

On June 23, 1462, she was at Chinon, in Touraine, where she executed a bond engaging to surrender Calais, if ever her lord recovered it, or to pay 40,000

a The surrender according to the recitals in the Act of attainder and resumption, 1 Edward IV., took place on St. Mark's Day, April 25. Rot. Parl. v. 478, col. 1.

b Rot. Parl. ibid.

c Paston Letters, ed. Gairdner, 386.

a Rot. Parl. ibia. Paston Letters, 391.

- "Mense Aprilis Regina Margareta per navem de Scocia adivit Franciam pro auxilio Regis Francie habendo."- "Die Parasceves Regina Margareta cum quatuor navibus de Kyrkhowbhryth in Scocia per mare inter Walliam et Hiberniam adivit Britanniam . . a ac posteà Andegavis ad patrem suum Regem Siciliæ et consequenter ad regem Francie pro auxilio habendo." Wyrc. 492, 493, events of 1461-2.

2 o 2 
livres. ${ }^{2}$ In consideration of this undertaking Louis advanced her 20,000 livres, and, with a force recruited in France, under command of Pierre de Brezé, Seigneur de Varennes, and Seneschal of Normandy, she set sail for Scotland.

This, it will be observed, was Margaret's First Voyage to the Continent.

During the Queen's absence her friends in Scotland would appear not to have been absolutely inactive, for we read in Hearne's Fragment that Piers de Brezé $^{b}$ in the second year of Edward IV. came out of Scotland and stole by

First surrender of Alnwick to Lancastrians, and re-capture
by Yorkists in summer of

1462 .

Q. Margaret lands in Scotland, October, 1462. treason the castle of Alnwick, whither were sent against him Sir William Lord Hastings, Sir J. Howard, and others, who besieged the castle, and de Brezé fell to agreement. Whereupon he, with his Frenchmen, departed the 30th day of July.

Wyrcestre confirms this to some extent. After mentioning Margaret's first voyage in April, 1462, and an embassy undertaken by Warwick to cajole the Queen of Scots, which we know was in June, ${ }^{\circ}$ he says that in July Lord Hastings and others besieged Alnwick, where William Taylboys, a notorious Lancastrian leader, was captured, who yielded on conditions, and Sir Ralph Grey (of Warke, ancestor of the present Earl Grey ${ }^{\mathrm{d}}$ ) was put in as governor for Edward.

Wyrcestre does not tell us how long Taylboys had been in possession of the castle, and says nothing about any Frenchmen. He informs us, however, of the capture of Naworth Castle about the same time by Lord Montagu, and adds that Lord Dacre surrendered to Lord Montagu on certain conditions. This castle had belonged to Ralph Lord Dacre, slain at Towton and attainted in the first parliament of Edward, and it may be concluded from Wyrcestre's note that, up to this time, Humphry, his brother and heir, had held it for King Henry. Upon the capture, however, he probably went over to King Edward, as we find him among other noblemen who in the winter of this year served in the expedition which resulted, as we shall presently see, in the re-capture by the Yorkists of the Northumbrian castles after their surrender to Queen Margaret.

Late in October, ${ }^{e}$ or early in November, ${ }^{f} 1462$, the Queen landed in Scotland

a The original bond is still in the French archives. See Douët d'Areq, Inventaire des Sceaux de France, num. 10,044. The tenor of the instrument is given by Miss Strickland, Lives of the Queens of England, iii. 269.

b There must, however, be a mistake in the leader's name, for it is sufficiently clear that de Brezé did not appear on the scene until November following, when he accompanied Margaret on her return from ler first voyage, as we shall presently see.

c See Archaoological Journal, xvii. 53, for a notice of a safe-conduct, dated June 17, 1462, from James III. of Scotland, for Warwick and the other ambassadors proceeding into Scotland.

d See sheet Pedigree, Raine's North Durham, facing p. 326.

e Wyrc. p. 494. Gregory, p. 218, says she landed in Northumberland seven days before All Hallow Tide, that is, about Oct. 25. This seems the most correct.

i Fabyan, fo. cexv. 
with her fleet, consisting it is said of 52 ships, carrying 2000 French and a few English. ${ }^{a}$

On piecing together the fragmentary statements of the available authorities, we may, I think, come to the conclusion that her plan of campaign, partly carried out, was to land her troops and, by conjoint operations by land and sea, to make herself mistress of the strongholds of the Northumbrian coast from Berwick to Newcastle.

I gather from Halle and Grafton, whose chronicles here run for the most part word for word together, that her sea force after landing the main body of troops (which was reinforced by a Scottish army) consisted of about 500 men.

These writers state that she sailed towards Newcastle and landed at Tynemouth. On her way she or her land force took Bamborough Castle, the most northern of the coast defences. The capture of this place was known in Denbighshire by November 1. ${ }^{\mathrm{b}}$ It was committed to the keeping of Henry, Duke of Somerset, the Earl of Pembroke, and Sir Ralph Percy, ${ }^{c}$ a younger brother of the Earl of Northumberland who fell at Towton and was attainted in the first Parliament of Edward IV.

Either then or, less probably, after her retreat from Tynemouth not long after, she attacked Alnwick Castle, the garrison of which, being short of supplies, yielded the place, and de Brezé's son, Lord Hungerford, Robert Whyttingham, and others were placed in it as a garrison. ${ }^{\mathrm{d}}$ Dunstanborough, situated between Bamborough and Alnwick, also fell to the Queen's arms about this time.

Fabyan (cexv verso) says that King Edward on having tidings of this invasion sped him into the north with a strong host; and John Paston, junior, writing to his father from Holt Castle in Denbighshire on November 1, informs him that my Lord of Warwick went forward into Scotland on Saturday (30 October) with 20,000 men. ${ }^{\mathrm{e}}$

a The number of ships is from Gregory-of men from W. Wyrcestre.

b Paston Letters, 463.

c Wyrc. p. 494.

d Wyrc. p. 494. "And there she took the Castle of Alnwick, and put it full of Frenchmen," says Gregory, p. 218.

e Paston Letters, 463. "Eodem anno, cirea festum Omnium Sanctorum percurrente rumore de adventu Reginæ Margaretæ cum copiosa multitudine Francigenorum, Scottorum, et Anglorum sibi adhærentium processit festine nobilis ille belliger comes de Warwik cum suis et subsecutus est rex Edwardus ut eam cum complicibus suis effugarent. Quæ, fugâ initâ, tuciora quæsivit præsidii loca." Brief Latin Chronicle, p. 175. 
This news seems to have alarmed the Queen, and, according to Halle and Grafton, the invading force which had landed at Tynemouth re-embarked.

Wyrcestre says, that, in company with de Brezé, the Queen fixed her camp at some place for which he leaves a blank, thinking that the whole country was ready to rise in her favour. No rising, however, took place, as her limited force inspired no confidence.

Q. Margaret abandons her expedition.
Margaret appears then to have determined to make off with her fleet to Berwick, where she seems to have left her son and (but this is not clear) her husband also, but, on the voyage from Tynemouth or whatever the turning point was, a storm arose, the result of which was very disastrous.

Gregory's account (I have here and elsewhere modernized the spelling) is as follows, "And then she returned (after taking Alnwick) into Scotland by water. And there rose such a tempest upon her that she forsook her ship and escaped in the ship's boat. ${ }^{a}$ And the ship was drowned with much of her stuff and three great ships more, and four hundred and six Frenchmen were taken in the church of Holy Island."

Fabyan tells nearly the same story. He says that the Queen, hearing of Edward's preparations, "brake her array and fled,* b and took a carvyle, and therein intended to have sailed into France. But such tempest fell upon the sea that she was constrained to take a fisher's boat, and by meane thereof landed at Berwick,* and so drew her to the Scottish king. And shortly after her landing tidings came to her that ${ }^{*}$ her said carvyle was drowned, within the which she had great treasure and other riches.* And the same day," Fabyan continues, " upon four hundred of the Frenchmen were driven upon land near unto Bamborough, where they for so much as they might not have away their ships they fired them, and after for their safeguard took an island within Northumberland, where they were assailed by one called Manners with others in his company, and of them slain and taken prisoners as many as there were." '

Halle and Grafton corroborate this, naming Holy Island as the seat of the

a "A small carvel," Halle and Grafton.

b The passages between the asterisks are nearly word for word with the narrative given in Hearne's Fragment, p. 291.

c At Bamborough. Hearne's Fragment.

d The Fragment, says, "seeing no remedy to scape they brent their ships and fled to an island thereby, where they were slayne and takin everychone," by certain gentlemen there. Fabyan seems to have had before him the Chronicle of which Hearne preserves a "Fragment," or the work on which it was founded, so near is their language. Fabyan, howerer, adds a few facts. 
adventure, mentioning "the Bastard Ogle and John Manners" as the assailants, and stating that many of the Frenchmen were slain, and nearly 400 taken and put to ransom. It is hard to understand why these French troops did not avail themselves of the shelter of Bamborough Castle, then in Henry's hands, if their wreck really took place off that fortress. ${ }^{a}$

I am not clear as to Henry's movements all this time; he no doubt remained in Scotland, whilst his Queen was on her French progress, "to see and espie," as Halle and Grafton say, "what way his friends in England would studye;" but whether, on her return with a land and sea force and with money, he ventured to cross the border at the head of the expedition thus undertaken, I cannut certainly find ont. Worcester, after narrating the capture of the three castles, says, "Rex Henricus vero cum Regina, Brasse et aliis, metu Regis Edwardi superveniente, adiverunt Scotiam," as if he was then in England, but the writer may only mean that he was in Berwick, and retired thence into Scotland.

Edward had left London on November the 3rd, and had marched up to the North, raising the country as he went. The three castles were besieged under his orders in December. ${ }^{b}$

We have an account of the disposition of the forces, with some other details, in a letter from John Paston the youngest, who was serving with the Duke of Norfolk. He writes from Newcastle on Dec. 11, 1462, stating that the castles were besieged "as on yesterday." "

A fragment of a similar letter, written probably from the seat of war about. the same day, is preserved among the Cotton Charters, xvii. 10. ${ }^{\mathrm{d}}$

A third account in Latin, but headed in English, "The Wednesday before Cristmasse, Anno Domini M.ccc.lxij"," is among the Brief Notes of these years, printed (pp. 158-9) in Mr. Gairdner's Three Fifteenth-century Chronicles.

Putting together the information derived from these three sources, we learn that the King was at Durham, and kept his Christmas there; that the Duke of

a A new, but I doubt if a very certain, light is cast on this passage by an assertion in Brief Notes, p. 156, that Margaret after taking Alnwick was besieged in Bamborongh. The writer adds a curious variation of the Holy Island story partly unintelligible to me, owing to the false Latin. I give it verbatim. " Regina Margareta cepit castrum de Anwyk et obsessa erat in castro de Banburw. Et cum cc Anglici intrassent quandam parvam insulam in illis partibus ad succurendum se si necesse fuisset, ipsis nescientibus, advenerunt cccc de Francigenis ad eos includendos et capiendos, et subito in Anglicos irrûerunt; sed capti et interfecti erant ex Francigenis cc et plures, et alii fugierunt ut dicitur."

b Wyrc.; Gregory, p. 219. Warkworth, p. 2.

a Printed in Excerpta Historica, Bentley, p. 365. c Paston Letters, p. 464.

e Stow has used this p. 417 . 
Norfolk was at Newcastle, apparently commanding the supports; and that Warwick lay at Warkworth Castle " but three myle owt of Alnewyk" (Paston), and that with him were "the Lord Crumwell, the Lord Grey of Codnor, and my Lord Wenlok." (Cotton Ch.)

The Yorkist army is estimated at from twenty to forty thousand men by the Cotton Fragment, besides "the King's Host," and the Brief Notes account for 30,000 men equally divided among the beleaguering forces. These numbers appear very excessive as compared with the small garrisons mentioned.

For curiosity's sake I have collated the three reports, and give the result in

Surrender of the castles, Christmas, 1462. a footnote. ${ }^{\mathrm{a}}$

On Christmas Eve Bamborough and on St. John's Day (Stow), Dunstanborough surrendered on conditions ; life and limb were to be spared, Somerset, Percy, and some others, upon swearing allegiance to Edward at Durham, were to have restitution of their forfeited lands. This agreement was carried out, and Somerset was received into high favour by the King. ${ }^{b}$ The custody of these two castles was given to Sir Ralph Percy, in accordence with another article in the terms of surrender.

\section{a Bamborough.}

Garrison. Duke of Somerset, Lord Roos, Sir Ralph Percy with 200 or 300 men (Cotton) [and the Earl of Pembroke. Brief Notes.]

Besiegers. Earl of Worcester (Cotton.) [He was at Dunstanborough according to Paston.] Lords Montagu and Ogle. Lords Strange, Say, Grey de Wilton and Lumley (Cotton.) [Also the Earl of Arundel and 10,000 men. Brief Notes.]

\section{Alswick.}

Garrison. Lord Hungerford, Sir Robert Whittingham (these two were old companions, an intercepted letter from them to Queen Margaret in Scotland written from Dieppe in August 30, 1461, acquainting her with the death of Charles VII. and cautioning her not to venture for the present to the Continent, will be found in Paston Letters, 413,) and Sir Thomas Fyndern and five or six hundred Frenchmen. [Brief Notes give the garrison at 300 men, and places Fyndern in Dunstanborough.]

Besiegers. Earl of Kent, Lord Scales and others (Cotton) [Earls of Warwick and Kent, and the Lords Powys, Greystock, and Cromwell with 10,000 men. Brief Notes.]

\section{Dunstanborough.}

Gartison. Sir Richard Tunstall, Doctor Morton (afterwards Bishop of Ely and Lord Chancellor) and Sir Philip Wentworth, 600 or 700 men (Cotton.) [Brief Notes add Sir T. Fyndern, "Ballivus de Kam" with six score men, but this must be a slip for six hundred.]

Besiegers. Lords Fitzhugh, Scrope, Baron of Greystock, Lord Powys (Cotton). Earl of Worcester and Sir Ralph Grey (Paston), but the Earl of Worcester was at Bamborough according to Cotton. [Brief Notes name Lords Wenlock and Hastings "with other Lords" as besieging this Castle, placing Greystock and Powys at Alnwick.]

b Wyrc. ubi supra. Gregory, pp. 219,220. This latter writer gives some curious particulars as to the good treatment Somerset met with at Edward's hands. 
The third castle, Alnwick, held out until Twelfth Day (Jan. 6, 1463). On the eve of that day news suddenly arrived of the approach of a body of Scots a under Pierre de Brezé, whose son, as we have seen, had been left with Lord Hungerford in garrison there.

Early next morning they drew up before the castle. Warwick and all his forces advanced to meet them, but, finding themselves outnumbered, declined action. $^{b}$ The besieged made a sortie, and young de Brezé, Hungerford, Sir Richard Tunstall, Robert de Whittingham, and others, joined the Scots, who withdrew unmolested. Wyrcestre says that if the Scots had only been bold and wise, they might have destroyed the English nobles. ${ }^{c}$ The Frenchmen who remained in the castle were given quarter and, surrendering, were suffered to depart.

Thus the northern strongholds were all for a short time in Edward's hands.

Sir Ralph Grey had expected to have been made captain or governor of Alnwick, but Edward, to the great disgust of Grey, gave the chief command to Sir John Ashley, Grey being made constable under him. ${ }^{d}$

Edward, as I understand Fabyan, had originally intended, when he found that Margaret had retired, to have pushed on and attacked the Scots ; however, " he was then visited with sickness ..... . so that he was forced to leave that journay." And after Alnwick was taken he went south, apparently to London. ${ }^{f}$

K. Edward and Warwick leave the north, early in 1463 .

a And Frenchmen, Brief Latin Chronicle, p. 176, followed by Stow, p. 417. Halle and Grafton inform us that the Scots were 13,000 strong, and were under the command of Sir George Douglas. The information may be correct; but, owing to these chroniclers having (as we shall see in the sequel) antedated the battle of Hexham by two years, it seems at first sight to refer to the second and final capture of Alnwick by the Yorkists after that battle, in 1464.

" "Nostris non audentibus eis resistere," Brief Latin Chronicle. "The English looking on," Halle and Grafton. "Videntes se inferiores numero," Wyrc. p. 495.

c Warkworth, p. 2, narrates this event in much the same way. He says de Brezé had 20,000 Scots with him, and that either party was afraid of the other. "Had the Scots come on boldly, they mighte have taken and distressed all the Lords and Commoners, for they had laid so long in the field, and were grieved with colde and rain, that they had no courage to fight." But these events are placed erroneously in 1 Edward IV. 1461.

a Wyrc. p. 496. Gregory, p. 220.

e See Brief Notes, p. 157, for the names of dukes, earls, \&c. including Lord Dacre of the North, with the King Edward "in hys jorny into Scottlong at the fest of $\mathrm{S}^{\mathrm{t}}$ Andrew in pe month of Decembyr. Anno Domini $\mathrm{M}^{0}$.cccc.Lxis ." Stow (p. 415, ed. 1631) has copied this list down to the first six knights, adding "to the number of fifty-nine knights," which number agrees exactly with the list in Brief Notes.

"Gregory, Brief Latin Chronicle. The Latin Chronicle here makes the following reflexion : "Et in hac tam longa morâ tocius pene milicie Anglicane illic adversus adversarios nostros congregate, quid, queso, memorabile, quid laude dignum actum est nisi quod predicta tria castra capta sunt ?"

VOL. XLVII.

$2 \mathbf{P}$ 
Recapture of the castles by French and Scots, Spring, 1463.

Q. Margaret's second voyage, April, 1463 .
Warwick, according to the Brief Latin Chronicler, remained a short time longer, maintaining the field with a few troops and keeping back the Scots. ${ }^{a}$

He then marched south and rejoined the King in London; but, "while they were merrymaking and I wot not what else," the Scots made a fresh incursion into Northumberland, and retook Bamborough and two other castles. Fabyan says this was about the time of Lent (Ash Wednesday in 1463 fell on February 23rd, and Easter on April 10th).

Sir Ralph Percy, it will be remembered, had been left in command of Bamborough and Dunstanborough. It was through his "collusion and treason," says Gregory, that the Frenchmen (he does not mention the Scots expressly) were allowed to take Bamborough from him " nolens volo." "

Sir Ralph Grey also, "that false knight and traitor, by false treason," says the same chronicler, took Sir John Ashley, the governor of Alnwick, prisoner, delivered him to Queen Margaret, and surrendered that castle "to the Lord Hungerford and unto the Frenchmen accompanied with them." $a$

Dunstanborough, I suppose, was the third castle referred to by Fabyan as being retaken at this time, for it was still in Lancastrian hands in 1464, and was retaken by the Earl of Warwick after Hexham.

After the surrender of Alnwick to Lord Hungerford, and about Midsummer, King Henry, the Queen of Scots, and Sir Pierre de Brezé, if we are to believe Gregory and Stow, who alone mention it, advanced with 4,000 Scots and laid siege to Norham Castle and lay there eighteen days. Warwick and Montagu, however, raised the siege, and Henry and the King (? Queen) of Scots were put to flight.

Margaret now disappears from the theatre of war. Whether, as Gregory ${ }^{*}$ would have us believe, in consequence of the hard pressure put upon her by Warwick and Montagu after the relief of Norham Castle, or from the loss of her treasure in the shipwreck and general despair of further success, coupled with a desire to place her infant son in safety, she undertook her Second Voyage.

Sailing from Bamborongh in April of this year in company with the Duke of Exeter, Sir John Fortescue, the famous Chief Justice, and others to the number

a So I translate " Scottos cum suis excuciens," Br. Lat. Chron. p. 176.

b "Epulantibusque illis Londini et nescio quid agentibus." Ibid.

- Gregory, and see Rot. Parl. v. 511.

a Wyrcester puts the betrayal of Alnwick in May, 1463, which was after Queen Margaret's departure on her second voyage. He says that Grey expelled Ashley, who fell into the hands of Sir Ralph Percy.

e Page 220. 
of two hundred, ${ }^{a}$ she landed at Sluys in Flanders, and was conducted to Bruges by the Count of Charolois (son of Philip the Good of Burgundy, and afterwards married to Edward's sister, the well-known Duchess of Burgundy, so troublesome to Henry VII.), who most abundantly provided for her. Afterwards the Queen was brought to the Duke of Burgundy at Lisle, where most piteously she declared her case of the loss of the Realm of England and begged for aid. The Duke comforted her and gave her [blank] thousand écus for her expenses, and sent her with her English attendants " in propriam patriam patris sui in Lotharingiam, ubi pater suus dedit sibi quoddam castrum valoris [blank] ut ibi expectaret eventus mundi :" b that is, that she might abide the course of events.

$I$ find no good reason for thinking that she ever returned to England until 1470, when the remarkable event occurred of King Henry's restoration for a few short months.

That this is not the current opinion I am well aware. As we shall see supposet further on, Margaret is commonly stated to have been present at the battle of cussed. Hexham, which was fought in 1464 .

Now the Queen's return to England after this second voyage is nowhere distinctly stated by any contemporary chronicler, ${ }^{\mathrm{c}}$ and there is direct evidence that she remained in France, as I have just said, until the year 1470.

Richard de Wassebourg, whose chronicle called Antiquités de la Gaule

a Wyrc. p. 496. Easter fell on April 10 in 1463, and, as we have seen, it was in Lent that the Scots, or Lancastrian party, retook Bamborough. She fled away, says Gregory, p. 220, with all her council, and Sir Pierre de Brezé and his Frenchmen (i.e. all who survived) by water with four balynggarys (vessels of some sort, ballengers, Froiss. See Ducange s. v. Balingaria): and they landed at the Scluse in Flanders, and left King Henry that was behind them, \&c.

b Wyrc. ubi supra. The particulars of the reception of the Queen in Flanders are given in Du Clercq and the continuator of Monstrelet, as referred to later on. According to Du Clercq (Buchon, Monstrelet, xiv. 297) Charolois was at Lille, the Duke at Hesdin. He says, the Duke gave her 2,000 gold crowns, de la Varende-as he calls Brezé-1,000, and each of her ladies 100 crowns, "et sy les feit convoyer hors de ses pays, et tant qu'elle fnst ès pays de Barois, ou estoit son frère, le duc de Calabre, qui en estoit seigneur."

c The statement in Hearne's Fragment, p. 294, that in the same year (1463) King Harry was taken in the north, and Edmond Duke of Somerset with his brother John were yet in Scotland with Queen Margaret, \&c. is of no value. Henry was not taken prisoner until 1465, and Edmond Duke of Somerset did not succeed to the title until 1464, when his brother Henry was beheaded after Hexham field. Indeed the passage is marked in the margin by a more recent hand: "False-for he (that is Edmond) was gon to the Burgon (i.e. to the low countries) the yere before." See Letter of Sir John Fortescue in Ld. Clermont's Hist. of The Family of Fortescue. 2nd edit. 1880, pp. 71-2.

2 P 2 
Belgique was finished about 1540 , and printed at Paris in 1549 , was a canon and archdeacon in the cathedral church of Verdun in Iorraine. His father, in reward of services rendered to King René, had been ennobled by that prince, and he himself shows such evident interest in the fortunes of the House of Anjou, that any particulars relating to that family which he records, may, I think, although he was not a contemporary writer, be accepted as most likely to be accurate.

At folio veix $b$ of his work, in connection with Margaret's second voyage, that is, to the Court of Burgundy, and thence into France, he says, using, it should be remarked, almost the very phrase of William Wyrcestre, that she remained there "attendant meilleur fortune." But this. is not all, for, at folio vexiii $a$, he mentions a summons by Louis XI. to King René, issued about June 1470, to meet him at Angers, accompanied by his daughter Queen Margaret and her son, who, says Wassebourg, "since their last return into France, which was in the year 1463, chiefly resided in the Duchy of Bar, which was part of the true patrimony of the King René, in the Château called Kneure (the margin calls it Keure), near the town of St. Michel (St. Mihiel in the modern maps), in our diocese of Verdun."

I may add to this testimony that of the anonymous continuator of the Croyland History, which I extract in the footnote. He has however overlooked, or omitter as unimportant, Margaret's first voyage and return to England. ${ }^{a}$

But to proceed with our account of the events of 1463 .

The Brief Latin Chronicle seems to me to throw a little new light on the military proceedings of the next few months; yet this is but darkness visible, as I must coniess. The writer, who gives stronger hints of dissatisfaction with Edward's strategy than we are apt to find in the colourless memoranda which for the most part compose our materials for the history of this time, starts with the meeting of Parliament on April 29, and the prorogation on June 18, "et quæ

a Hist. Croyl. Contin. Gale Script. i. 533. After a description of Towton field, he says, "Fugit etiam cum paucis eodem temporis articulo Rex Henricus in Scotiam, ubi continuè et in castris eidem conterminis, per quatuor postmodum annos in magnâ delituit confusione. Regina verò Margareta cum filio suo Edwardo, quem de præfato susceperat Henrico, etiam fugæ consulens, non cito denù̀ reversura, in partes interim secesserat transmarinas."

b 'This date is correct, Rot. Parl. v. 498. The prorogation was not on June 18 th but on the preceding day, and the reason assigned was the king's enforced absence to oppose his enemies of Scotland and his traitors and rebels. The prorcgation was until November 4 th. 
mala ibi repressa aut reformata, vel quid boni ibi adauctum nescio." Then he states, that after Whitsuntide (Whitsunday fell on May 28 in 1463) the Farl of Warwick went north, ${ }^{\mathrm{n}}$ collected an army, and set himself to harass the party of Henry and his Scots, Frenchmen, \&c., who fled on his approach. Possibly this sentence refers to the relief of Norham already mentioned, but of which we have not the exact date, and that it was during this expedition that occurred the recapture of Berwick-on-Tweed by the stout Earl which Stow records.

It was apparently early in September, "post festum Nativitatis Beatissime k. Edwarl's Marie Semper Virginis" (September 8), that Edward himself raised a great army, and addressed himself to the task of subduing his adversaries by land and sea. expedition to the north, "Nescio tamen quid in illo viagio profecerit."

The Earl of Worcester had the command of a fleet, but achieved no success. The chronicler's words are worth quoting, "Et comes de Worcester cum suo navigio (navy) et marinariis, litoribus maris et portubus quasi latitantes, annonasque suas consumentes infecto negocio vacui cum dedecore remearunt. O infelix successus, opprobrium et confusio."

Gregory is to the same effect (p. 221), "Then the King Edward the Fourth purposed to make an army into Scotland by land and by water, that the great rebellious Harry and the Queen Margaret should not pass away by water." Here is a distinct hint of an attempted invasion of Scotland, but as to Margaret, Gregory forgets that a few lines previously he has plainly told us how that she, de Brezé, and the rest, had already left and got them to Flanders. He proceeds, "And the King made the Earl of Worcester captain by water. And then there was ordained a great navy and a great army, both by water and by land. And all was lost and in vain, and came to no purpose, neither by water nor by land."

It is disappointing not to find what the "great navy and army" attempted to do. One thing is clear, that the North remained very unquiet. The three Northumbrian castles of which we have heard so much, and probably other fortified places of less importance, were still in Lancastrian hands. Danger from Scotland seems still to have been apprehended, and it was not until October 27 th that a truce with France was proclaimed, to date (for the French) from October 20, 1463, and for England, Ireland, and the Isles, from November 15, to last until

a Commissions of array were issued on June 2, 3 Edward IV. (1463) under the Great Seal, because the French and others intended to invade the realm; Warwick was constituted warden of the West, and Montagu of the East March. Rymer, xi. 501. 
October 1, 1464, Louis undertaking to show no favour either to Henry or to Margaret. A truce with Scotland was also arranged in December."

We come at length to the year 1464. The Parliament, no doubt on account of the unsettled state of affairs, had been further prorogued before the appointed day of meeting to February 20, at York.

Early in this year, as I gather from the Brief Latin Chronicle, and from other sources, Henry began to move again.

This chronicler is, I think, the only one who informs us that, while Edward was feasting with his lords in London, the partizans of the deposed monarch seized the castles of Norham and Skipton in Craven, wherupon Edward again made for the North to recover what was lost and defend what remained to him, "Quid tamen utile ibi gesserit nescio." b Somerset, who had hitherto continued with Edward, about this time again changed sides, and made off to join King Henry.

The Parliament was again adjourned, to meet at York on May 5th. ${ }^{\text {d }}$ But

Battles of Hedgcley

Moor and Hexham, $\Lambda$ pril and May, 1464. before this day came, the Lancastrians were encountered by Lord Montagu ${ }^{e}$ (who had shortly before taken the field) at Hedgeley Monr on St. Mark's Day (April 25), and at Hexham on May 8, 1464, and were completely routed. Henry himself was present at the second battle, and was all but taken prisoner.' He escaped,

a Rymer, xi. 509, 510.

b Brief Latin Chronicle, 1. 178, see Mr. Gairdner's preface, p. xxiv.

c Gregory, p. 223. This is also mentioned in most of the books.

a Rot. Parl.v. 499.

e Fabyan, sub annis 1463-4. "In this yere and moneth of May, whyche was in the begynnyng of the iiij yere of King Edwarde, Lord John of Montagu, havinge then the rule in the northe partes, beynge warned of the comyng of Henry late kynge wyth greate power out of Scotland, assembled the northyn men, and mett with hym about Exam, \&c." Not a word, be it observed, about the presence of Queen Margaret. The movements of Montagu immediately before the battles are given with some little detail by Gregory.

f An episode of the battle of Hexham is not without interest. The author of the Brief Latin Chronicle, after noticing the battle, says-" Deliberata sunt in breve domino de Mowntagu castra de Langeley the Tawne, Turris de Exham; castrum etiam de Bywell. In quo quidem castro inventum est le helmet regis Henrici cum coronâ et gladio et faleris dicti Henrici. Et quo modo aut quo ipse evasit, novit deus, in cujus manû corda sunt Regum. Camd. Soc. p. 179."

"John, Lord Montagu," says Fabyan, (ccxv. v".) " after the battle of Hexham, chased Henry so nere, that he wan from him certayne of his folowers trapped with blewe velvet, and hys bycocket garnysshed with two crownes of golde, and fret wyth perle and riche stone." 
however, possibly into Scotland, but, as is well known, was captured in Lancashire not many months afterwards, and was conveyed to the Tower of London, and kept there until 1470.

These two notes of trophies taken from Henry on the occasion of his flight differ in describing the head-piece as a "helmet" and as a "bycocket." They may or may not both mean the same thing. What a "bycocket" was we shall see presently, but first I wish to call attention to the wonderful transformations which the word itself has undergone at the hands of the later chroniclers.

Halle (followed by Grafton), with a sneer at this unfortunate prince, says " King Henry was the best horseman of his company, for he fled so fast that no man could overtake him, and yet he was so near pursued that certain of his henchmen and followers were taken, their horses trapped in blew velvet: whereof one of them had on his hed the said King Henry's healmet. Some say his high cap of estate called abococked (Halle, fol. ii. $\mathrm{v}^{\circ}$ ), Abococket (Grafton, ii. 661), garnished with two riche crowns, which was presented to King Edward at Yorke, the fourth day of May."

The word seems to have puzzled the printers. Halle first misprints abocorked for a bycocket, and then Grafton restores the $\mathbf{t}$, but throws the indefinite article into the word with a capital $\mathfrak{A}$. Holinshed has further improved on Grafton and turned the head-piece into $\mathfrak{A b}$ acot.

Spelman in his glossary has got hold of this monstrous corruption, "Abacot," from Holinshed, whom he quotes, giving the definition "Pileus augustalis Regum Anglorum duobus coronis insignitus." And from Spelman (or from Holinshed), Bailey, Ash, and, I believe, other English dictionary makers have inserted the ridiculous word.

The first article in the late Mr. Planché's Cyclopcedia of Costume is on "Abacot, Abocked, Abocket, Bycocket." This very agreeable and learned writer has failed, probably from quoting at second hand, to see that the true word is Bycocket, and that Abacot, \&c. \&c. are mere corruptions. But I think he has shown clearly and for the first time what a Bycocket is.

Willement in his Regal Heraldry quotes a passage from Leland's Collectanea, iv. 225, giving an account of the Coronation of Queen Elizabeth of York, on which occasion the Earl of Derby as Constable of England entered Westminster Hall, " mounted on a courser richely trapped, and enarmed (that is to say) Quarterly, Golde, in the first quarter a lion gowles, having a man's head in a Bycockett of silver, and in the second a lyon of sable. This trapper was right curiously wrought with the nedell, for the mannes visage in the Bycockett shewde veryle (? fayrle) well favorde.

Willement is inclined, but no doubt wrongly, to connect this curious bearing with another device borne in a banner at Elizabeth of York's funeral. Mr. Planche, however, more judiciously observes that the device of a lion with a man's head in a "bycocket" did not belong to the Stanleys. But, says he, it is to be seen in a standard of John Ratcliff, Baron Fitzwalter (Book of Standards, Coll. Arms,) and he finds that Fitzwalter and others were associated in 3rd Henry VII. for exercising the office of High Steward of England at Queen Elizabeth's Coronation." It is therefore clear that it was Lord Fitzwalter as High Steward, and not the Earl of Derby as constable, who rode the courser so " trapped and enarmed."

Mr. Planché in his Plate I. lettered, I am sorry to say, " Abacot," instead of " Bycocket," figures the man-lion from Fitzwalter's standard, temp. Henry VII. where the Bycocket on his head is evidently identical with the so-called cap of estate or cap of maintenance, of which his drawings on the same plate show examples from the seals of Edward the Black Prince and Richard Duke of York, and from the grant to John de Kingston by Richard II. Harl. MS. 5804, with other specimens. After remarking "that 
Lord Montagu, the victorious general, was created Earl of Northumberland by King Edward at York, on Trinity Sunday (May 27), 1464. ${ }^{\mathrm{n}}$ Accompanied by his brother, the Earl of Warwick, he laid siege on June 25th to Bamborough Castle, which fell to their assault after a short bombardment. ${ }^{6}$ Alnwick and Dunstanborough had already surrendered.

the (Abacot or) Bycocket was not peculiarly a royal cap of state appears from an entry in a fifteenth century MS. (L 8, fol. 54 b. Coll. Arms) entitled 'The apparel for the field of a baron in his Sovereign's company; Item, another pe. (? paire) of hostyng harness [to] ryde daily with all, with a bycocket, and alle other apparel longynge thereto," he goes on to say, "It is, I think, evident, that the (abocock or) bycocket was the cap so frequently seen in illuminations of the fifteenth century turned up behind, coming to a peak in front, varying and gradually decreasing in height, encircled with a crown when worn by regal personages, and similar to if not identical with what is now called the knight's chapeau, first appearing in the reign of Edward III. and on which (when used upon a helmet) the crest is placed."

The word is French, but of uncertain derivation. Under the word Bigacia, Ducange says "Bicoquet vero, et biquoquet, ornamentum est capitis, capitii species, in Addit. ad Monstrel. anno 1465, fol. $10 \mathrm{v}^{\circ}$. Un Breton, archier de corps du duc de Berry, accoustré d'une brigandines . . . . et un Bicoquet sur son chief, garri de boutons d'argent doré." He cites also a will dated 1473 containing a bequest of a "Biquoquet fourni d'argent." Roquefort gives the word with the same meaning. I cannot find it in any of the other old French glossaries which I have been able to consult, and M. Littré has not included it in bis great French Dictionary.

There is some authority, at least so M. Viollet le Duc seems to think, for a bicoquei having at one time been a particular kind of helmet. See Planchés Cyclopcedra, i. v. Bycocket, a distinct article, in which he discusses this opinion.

a Patent 4 Edward IV. $1^{\mathrm{a}}$ pars. m. 10, Carte rightly gives the date of this creation as May 27, and Wyrcestre, p. 499, agrees with this: "Dominus Rex postea (i.e.post praelium apud Hexham) in festo Trinitatis pro honore captionis dicti ducis Somersetiæ creavit prædictum Dominum Mountagu in Comitem Northumbriæ, deditque eidem Comiti omnia dominia et terras quæ quondam fuerunt Henrici Percy infra Comitatum Northumbrix." Yet in a patent passed May 26, 4 Edward IV. John "Earl of Northumberland and Lord of Montague," has commission to treat for peace with Scotland. (Rot. Scot. 4 E. IV. m. 14.)

And the narrative of the siege of Bamborough (MS. Coll. Armor.) printed in Warkworth, Note, p. 36, and in Bohn's Chronicles of the White Rose, a useful little book, begins "May 27, Anno Domini 1464. The King lay in the palace of York and kept his estate there solemnly, and there greated he Sir John Neville Lord Montague Earl of Northumberland."

Dugdale, Bar. i. 307 refers to the same patent roll, but to the wrong membrane, 6 instead of 10 , and dates the patent May 23.

The creation is dated by subsequent writers (all incorrectly) as follows:-

Burke Extinct and Dormant Peerages . . . 1461

Banks Extinct and Dormant Peeragee . . \ 1463

H. Drummond, Noble British Families (Neville)
Nicolas' Historic Peeräge, by Courthope . . . 1465, May 27

` Radulfus Gray fugit de Hexham ante bellum inceptum ad castrum Bamburghe, et post bellum de 
The North was now finally subdued for the dominant party. The only place, The Yorkists indeed, in the realm which held out after this for Henry was the strong castle of the situation, Harlech, which had once afforded a shelter to his fugitive Queen, and continued, under its gallant defenders, David ap Jevan ap Einion, and Reynold ap Griffith ap Pletheũ, to hold out until taken by William Herbert, Earl of Pembroke, in 1468. ${ }^{\mathrm{a}}$

The Parliament, which had been again prorogued to meet at York on November 26th, was further adjourned to Westminster, where it met for the despatch of business on January 21, 1464-5, 4th Edward IV. ${ }^{b}$

One of the first things done was to pass a bill of attainder against the Lancastrian leaders, including the late Duke of Somerset, Sir Ralph Percy, and others. $^{\mathrm{c}}$

The Duke had been taken at Hexham, and was then and there beheaded. This nobleman, nearly related to King Henry, had been placed by him in positions of high trust, and, after Towton Field, in the Parliament of the first year of Edward IV. was attainted as a principal adherent of the deposed King. Afterwards, as already observed, he changed sides and was restored in blood, but, having returned to his old allegiance, he commanded the Lancastrian forces at Hexham.

The recitals to the subsequent Act of Attainder of Somerset and others arc conclusive as to the dates of both battles. ${ }^{a}$ They narrate how that Henry late Duke of Somerset, now dead, was attainted anno primo, and in this present Parliament restored to his honours and dignities, and nevertheless "took his viage prively oute of the parties of North Wales ${ }^{e}$ unto he came into the shire of Northumberlond, where Henry late called King . . . kept traitorously and rebelliously the King's castles of Bamborough, Dunstanborough, and Alnwyke .... and with hym confedered to the distruction of our said Sovereign Lord by battaill and to the same entent and effect at Exham in the said shire the eighth day of May, in the said fourth year, rered werre ayenst our said Soveraygne Lord."

Hexham multi ex parte Regis Henrici fugerunt in eodem castro. Et non longò postea comes Warwick cum maximis bumbardis obsedit idem castrum. Wyrc. p. 499. Fabyan, p. cexvi. mentions also the capture of Sir R. Grey, and the fall of the castle. Grey was beheaded at Doncaster as soon as his wounds were cured.

a Mr. Halliwell's Notes on Warkworth, p. 34. See Rot. Parl. v. 512.

b Rot. Parl. v. 500, 508.

c Ibid. v. 511.

a Rot. Parl. ibid.

e See Gregory, pp. 220, 223

VOL. XIVIr. 
And, again, how that " Rauf Percy knyght after long abode in rebellion was also received into grace and great trust, but against his duty delivered Bamborough and Dunstanborough traitorously to "Henry the Kynges enemye; and after that, on the feast of St. Marc Evangelist, in the said fourth year, at Heggelay More in the said shire of Northumberland, ayeinst our said Soverayne Lord rered war."

Here I conclude my summary, a reference to which will, I hope, make what follows easier to be understood.

As we have left off with the defeat and execution of Henry, Duke of Somerset, it will be convenient if we commence by examining Sir W. Dugdale's account of that matter, as given in the Beaufort genealogy, Baronage, ii. 124.

This is far from accurate. First he says that the Duke, to ingratiate himself with Edward, surrendered Bamborough Castle to him. This, as we have seen, was at Christmas 1462. He proceeds thus: "Also that the year next following (scilicet An. 1463, 3 E. 4), hearing that Queen Margaret was returned out of France into Scotland, with considerable forces, and that she had entered Northumberland, taken the castle of Bamburgh, and was marching on towards the Bishoprick, he revolted again and fled to the Lancastrian party."

Cause and effect are here inverted in order. Somerset's surrender of the castle at Christmas 1462 was the result of his having been already placed in it by Margaret or under her orders in the previous November. It was not until 1464 or, at all events, very late in the previous year, that he returned to his old allegiance.

"But this shifting (Dugdale continues) proved fatal to him, for John Nevill, then Lord Montacute, upon the news thereof [really upon the news that Henry was stirring in the north], being sent into Northumberlaud with a great power, gave them battel near Hexham, where, the Lancastrians being routed, this Duke Henry was, amongst other of the chief in that encounter, taken prisoner and then beheaded, 3 Apr. 3 E. 4."

The historical facts are vouched by reference to Holinshed, and the date 3 Apr. 3 E. 4 by reference to Esch. 8 E. 4 , n. 54 .

The inquisition thus referred to returns that "predictus nuper dux (Henry, Duke of Somerset) obiit tertio die Aprilis anno Regni dicti domini Regis nunc tertio." This finding, however, though rightly quoted by Dugdale, is plainly mistaken, the death being a full year too soon. It is to be observed that the inquisition was not taken until four years after Somerset's death, and the exact 
date of that event may have been, by that time, and for the immediate purpose of the inquisition, a matter of minor importance.

It is worth remarking that the inquisition of $8 \mathrm{Edward}$ IV. had already misled the usually accurate Vincent. In his Discovery of Errors, \&c., p. 480, he takes "Master Brooke" to task for asserting that Somerset was beheaded immediately after the battle of Hexham in 1462; and would set him right by quoting this inquisition, and so placing the battle and the execution in 1463 , the true date being 1464 .

Dugdale concludes by stating that afterwards, scilicet in 5 Edward IV., the Duke was attainted in the Parliament held in that year.

Sandford (Genealogical History, ed. Stebbing, p. 385) cites the same record and dates the duke's death 3 April, 1463, and as taking place after his capture at Hexham. ${ }^{\mathrm{a}}$

Collins in his Peerage repeats Dugdale's mistake, and his editor Sir Egerton Brydges has not corrected it.

Neither has Mr. Courthope in his edition of Sir N. H. Nicolas's Historic Peerage; for he says that the duke "being taken in arms against King Edward IV. at the battle of Hexham was beheaded 3 April, 1463."' He makes a further mistake in adding that in the Parliament which met 29 April, immediately after his death, the Act of Restitution in his favour was declared null and void, so that his honours fell under the former attainder (of 1 Edward IV.) and were again forfeited. We have here the month and day of the original meeting of the Parliament in 1463 which then restored him, instead of January 21, 1465, when, as we have seen, the second attainder or reversal of restitution, was really passed.

Dugdale, as already mentioned, quotes Holinshed for the wrongly dated events of the Hexham campaign; but Holinshed has done no more than abridge Halle (or Grafton), for, excepting a few flourishes of Halle's which Grafton has omitted, the two books in this part agree (as already mentioned) almost exactly.

Holinshed, it may be sufficient to notice, gives the year date 1463 in his margin p. 666, opposite to the account of Hexham, places the Queen's first voyage as it would seem in this year, and, indeed, does not change the year date

a I have to thank Mr. C. T. Martin, F.S.A. for his kindness in verifying Dugdale's citation of the inquisition mentioned above. He informs me that a second inquisition also referred to by Dugdale (Esch. 5 Edward IV. No. 38) a few lines lower down, gives no date of the Duke's execution.

b It may here be noticed, that Banks Extinct and Dormant Baronages, ii. 262, Courthope's Nicolas's Historic Peerage, and Burke's Extinct and Dormant Peerages, all agree in heheading Robert Lord Hungerford, another important Lancastrian commander, at Hexham in 1463, instead of 1464. 
until after the batties, the King's flight, Somerset's execution, and the final retaking of the castles and the creation of Montagu as Earl of Northumberland.

Halle himself, it must be observed, states the sequence of events pretty accurately, but the blunder of two years underlies all his story.

Thus, in his account of the second year of Edward IV. 1462, he anticipates the events of the fourth year by placing in the former year the battles of Hedgeley Moor and Hexham, the capture and execution of the Duke of Somerset, and the final recapture of the castles. Indeed, he has either overlooked their previous capture or has confounded the two events, ${ }^{\text {a }}$ for he mentions but one military cperation of the kind.

Still treating of the second year, Halle makes Edward return to York and create Lord Montagu Earl of Northumberland. He then introduces the events of 1463 by a statement which he got from Polydore Virgil or a common source.

Polydore (p. 513, ed. 1546), after giving, with great brevity and without exact date, a notice of the battle of Hexham and the execution of Somerset and others, proceeds thus :-

At rex Edouardus, etsi eâ novâ victoriâ res demum suas satis confirmatas esse pro tempore arbitrabatur, tamen magnoperè curabat, ut ne Margarita Henrici uxor ad solicitandos hominum animos in Angliam rediret, quocirca toto littore præsidia disponebat, maritimos aditus claudendi causâ, scribebatque ad singulos meridionalis oræ populos, ne mulierem venientem reciperent, néve ulla re juvarent, . . . . ad eam item partem, quæ ad Scoticum agrum pertinet, custodias habebat, ne quispiam ad Henricum ex regno adiret.

All this clearly belongs to 1464, and agrees with the presence of Henry as a fugitive in Scotland and with the residence of Margaret on the continent.

But, in translating or adapting the passage, Halle has altered the sense to suit his false chronology ; for he says that Edward provided against King Henry

a This is the most probable, forHalle makes Queen Margaret give the custody of Bamborough to Sir Ralph Grey, who, as we have seen, was in 1462 on the Yorkist side, but, having changed party, defended the same castle in 1464, after Hexham was taken, when the place fell, and he was beheaded as above stated. And again, before mentioning the taking of Bamborough (1462) he tells how Margaret took Alnwick, and says she made de Brezé captain there, and that he held it with his Frenchmen till rescued. It was de Brezé's son who was really left in Alnwick and rescued by his father in the first week of 1463.-Vide ante. Halle afterwards gives (as above) the story of the rescue, but puts it after Hexham-thus confusing it with the final reduction in 1464 . 
or Queen Margaret remaining in England, to which end he edified bulwarks, \&c., wrote to the south parts in no wise to receive the Queen or aid her, and set watches for her on the Scottish border, as Henry and his company lay then sojourning in Scotland.

He then relates Henry's entrance into England in disguised apparel and his subsequent capture as in 1463, twelve months and more too soon, and then says that the Queen, hearing of the captivity of her husband, departed out of Scotland and sailed into France, where she remaired with her father until her unfortunate journey into England again, where she lost both husband and son.

This departure is of course rightly dated in 1463, but the error in date of the Hexham campaign has produced all this confusion and the impression that Margaret was still in Scotland after the battle.

These mistakes in the date of the battle so often named are old enough. For example, The Chronicle of the Grey Friars of London (Camden Society), which has the air of a contemporary authority, has at p. 21 the following entry:-

Edwardus Quartus Rex .... iij $^{\circ} \mathrm{A}^{\circ}$.

.... And this year was the battelle of Hexham felde.

The Short English Chronicle, again, p. 79, confuses the first with the second taking of the castles by the Yorkists, noting the siege of Bamborough, the bombardment and the beheading of the captain Sir R. Grey at York (it should have been Doncaster) in "Anno ii." instead of Anno iv. This chronicle also places the battle of Hexham in Anno iii. 1463.

Hearne's Fragment also antedates the action, referring it to " the same year as that in which Queen Margaret returned from France," id est, in 1462, after her first voyage.

Again, Rastell's Chronicle, printed in 1529, places the battle in the second year of King Edward; " while Habington's History of Edward IV. written about 1640, and printed by Bishop Kennett, in vol. 2 of his History of England, says it was fought in $1463 ;^{\mathrm{b}}$ and, in a footnote, quotes Holinshed for the statement which he thus amplifies :-

"The miserable queen, seeing the desolation of her greatness, her husband imprisoned, all her great friends fled or slaughtered, made again her retreat into France." 
To conclude the list, I will only add, that Speed also dates the battle as taking place in 1463, and that Yorke, in his List of "Battels," at the end of his Union of Honour, p. 36, thrusts the taking of Bamborough (in 1462) into the same year, right this time, as the battle of Hexham, 1464. ${ }^{a}$

Coming to more modern writers it is perhaps no matter for surprise that, with such an array of respectable authorities in her favour, Miss Strickland, in her Life of Queen Margaret of Anjou, should have fallen into the common mistake as to the date of the battle. She has also been led into giving a very romantic but curiously inaccurate version of the famous story of "The Queen and the Robber," and it may not be uninteresting to make some little investigation into the anecdote, and the authority on which it rests.

Our popular authoress's tale ${ }^{b}$ may thus be abstracted: In the spring of 1463, she says, Sir Ralph Percy was defeated and slain at Hedgeley Moor by Neville Lord Montagu, and that a few days later, "England was again set on a field" at the fatal battle of Hexham; and so she proceeds to notice King Henry's escape from the fight, continuing her narrative thus: "When the victorious Yorkists broke into the camp at Levels (Hexham Levels) Margaret ... fled with her son on foot into an adjacent forest, where . . . she unfortunately fell in with a gang of robbers, who . . . surrounded and despoiled her and her son of their jewels and costly robes of estate. While they were quarrelling about the division of the plunder, Margaret ... snatched up her son in her arms, and fled to a distant thicket, unobserved by the pitiless ruffians, who were deciding their dispute at the sword's point. When the shades of evening closed round, the fugitive Queen and her son ... began to thread the tangled mazes of the forest, dreading above any other peril the misfortune of falling into the hands of King Edward's partisans. . . . While Margaret . . . was considering what course to pursue, she perceived, by the light of the moon, another robber of gigantic stature advancing towards her with a drawn sword. Gathering courage ... she took her son by the hand, and presenting him to the freebooter . . said, 'Here, my friend, save the son of your king.' Struck with astonishment at the majestic beauty of the mother ... the robber dropped his weapon .... and offered to conduct them to a place of safety. A few words explained to the Queen that the outlaw was a Lancashire gentleman, who had

a Warkworth gives the date correctly, so does Stowe, whose aceount of the three years $1462-4$ is very accurate. He notices the first and second captures of the castles by the Lancastrians in the right places.

b Lives of the Queens, 2nd edition, iii. 271. 
been ruined in King Ifenry's service. . . . He led the Queen to his own retreat, a cave in Hexham Forest, where the royal fugitives were refreshed," \&c. \&c.

The Queen, after her rencontre with the robber, meets de Brezé and others of her friends, who inform her of. her husband's flight and the execution of Hungerford and others. They take leave of the outlaw and his wife, who by refusing payment for her hospitality gives occasion for a fine speech on the part of the Queen. She resolves to proceed to Scotland, and crossing the Solway lands at Kirkcudbright, in company with de Brezé and his squire. There she is recognised by a certain Englishman called Cork, who determines to betray her. He contrives to hurry the whole party on board a vessel, and puts to sea. The French knight and squire overpower and slay the crew, and the boat is driven on to a sandbank off Cantyre, where de Brezé lands the Queen on his shoulders, the squire performing the same office for Prince Edward.

The party then contrive to reach Edinburgh; thence, after a while, they proceed to Bamborough, and from that place accompanied by Sir John Fortescue and others the Queen and Prince sail to Sluys, as we have seen they really did, only it was a year before the battle of Hexham. The tale concludes by the historical fact of the Queen's reception at Bruges and passage to her father's country.

Miss Strickland's authorites for all this are Monstrelet, "Wassabourg," Carte, Barante, and Prevost, all referred to without either chapter or verse.

Wassebourg, Barante, and Carte are soon disposed of.

The first, so far as I can make out, from a careful examination of his book, does not even allude to the adventure. Miss Strickland calls him a contemporary well acquainted with Margaret. This he certainly was not, for he wrote in the days of Francis I.

Barante is a modern author of a history of Burgundy. He mentions the Queen's landing at Sluys and reception at Bruges, and tells the adventure as if it happened in 1463, but after Hexham.

Carte, a writer of the last century, dates the battle correctly, but imagines that Margaret was present at it. He merely says the woods about Hexham are the likeliest scene for Monstrelet's tale, which he proceeds to give. ${ }^{\mathrm{a}}$

As to Monstrelet, he died in 1453, some years before the incident could possibly have happened, and assuredly he did not, as Miss Strickland asserts ${ }^{\text {b }}$ was the case, have the story from the Queen's lips.

a History of England, ii. 767.

b Page 273, note. I can find in the pseudo-Monstrelet no suggestion of the kind. 
The tale is indeed to be found in the third book of the collection called

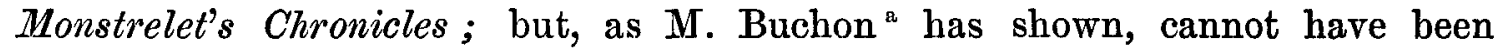
written by Monstrelet. He adds that, in the portion which extends to 1467, the text of Du Clercq is followed, but mutilated and confused in the order of chapters and dates.

Now Du Clercq records, as in 1462, King Louis' assistance given to Margaret, in the shape of 2,000 fighting men, under de Brezé, and the want of success of the expedition, which is set down to Somerset's defection." Here he stops to narrate several events of Flemish history in 1463, and so concludes his fourth book. Of these events, one only, the death of Robert le Jeune, governor of Arras, April 12, 1463, is copied by the pseudo-Monstrelet, p. 95 verso. Du Clercq's fifth book begins thus :

Environ ce temps la royne d'Angleterre ...... comme elle passoit par une forest en Angleterre, elle et son fils, pour garandir son fils, elle fut prinse des pillards, lesquels l'euissent mis à mort, si dissention ne fut meue entre eux, pour le butin des joyaux d'icelle dame; et ainsi qu'ils se combattoient icelle dame print son enfant et s'enfuia en la forest, auquel elle fust contrainte de lasseté de bailler à un brigand de bois son enfant, en lui disant, "Saulve le fils de ton roy ;" et ainsi échappa des mains des pillars, et depuis alla en Franche devers le roy Lois qui estoit germain à elle et ì son mary . . . . ; lequel roy Loys lui baillia le seigneur de la Varende, chevalier, avec certain nombre de gens d'armes pour aller avecq. Laquelle le mena pour cuider entrer en Angleterre, par le moyen d'aucuns ses amis et ses alliés qu'elle avoit oudit (en le dit) pays. Mais

a See the Introduction to vol. x. of his Edition of Monstrelet, published in the Collection des Chroniques de France.

b Buchon, Monstrelet (Supplement), vol. xiv. ch. xliii. p. 213. The whole passage, which contrins some curious details omitted in the pseudo-Monstrelet, may be worth transcribing, as the chronicle is not very familiarly known. "En ce temps Loys, roy de Franche, pour fair secours à la royne d'Angleterre, envoya deux mille combattans en Angleterre, dont estoit capitaine messire Henry de Brésil [Pierre de Brezé] chevallier, seigneur de la Barende [Varennes], lequel avoit, du temps du roy Charles, totalement gouverné tout le royaume; et. disoit-on, que le roy l'y envoyoit pour tant qu'il ne l'aimoit point, adfin par adveriture qu'il demourast là. Toutesfois, il sy porta si sagement au commenchement, qu'il y conquesta plusieurs places, ésquelles ils se tindrent certaine espace, attendant le secours du duc de Sombreset, Jequel leur avoit promis d'amener secours de gens, et avecq ce d'amener grosse armée d'Escoche; lequel duc le trahit, car ce temps pendant, il fit tant qu'il olt sa paix au roy Edouard d'Angleterre, et se lui rendit ledit roy sa duché et ses antres terres; et par ainsi faillit aux Franchois de sa promesse, et si n'eurent, par ce moyen, nuls secours d'Escoche; et furent, par le comte de Warwicq adsiègés èsplaces qu'ils tenoient, où ils ne se fuissent point tant tenus s'ils n' euissent attendu secours. Enfin il leur fust de necessité, après qu'ils olrent mangié, par famine, plusieurs de leurs cheraux, d'eux rendre, leurs vies saulvées; et s'en retournèrent plusieurs ung petit baston en leurs mains qui estoit blanc; mais ains qu'ils partissent, estoient allés en Escoche pour avoir secours, où ils faillirent de l'avoir. Durant lequel temps y olt plusieurs escarmonches et rencontres, où il y olt plusieurs mort d'ung costel et d'autres, et aussi plusieurs Franchois prisonniers.' 
ils n'y feirent rien, et n'y entrèrent point. Quant elle veit qu'elle avoit failly, elle trait à garand à l'Escluse (Sluys), qui est ung port de mer au pays de Flandres, avecq sondit fils et le seigneur de la Varende, et (laissant?) le roy Henri, au pays de Galles, en Angleterre, en une moult forte place; de l'Escluse elle vint avecq sondit fils et le seigneur de la Varende à Bruges auquel lieu elle fut recue honorablement, \&c.

This, I suppose, is the earliest extant version of the French story. The conclusion of it induces some perplexity, for, on the one hand, it is somewhat difficult to see why the same chronicler who in his preceding book had stated at some length and with accuracy, "as one having knowledge," the fact of Margaret's visit to Louis, and subsequent expedition with de Brezé, should revert to these incidents and give them again less completely and less correctly; while, on the other hand, I can hardly believe that, between her leaving England in 1463 and her landing at Sluys, Margaret could have visited Louis a second time, and could have made, under his auspices, an abortive attempt at a new landing in England.

Be this as it may be, it leaves unattacked my position that Queen Margaret did not return to England after April 1463.

Du Clercq, moreover, has no notion of the adventure happening after Hexham. He knew of that battle, and mentions it with the exact date at the beginning of his tenth chapter of this book; besides, he distinctly says that afterwards, depuis, the Queen went off to France, and, if we reject the idea of a second and elsewhere unrecorded visit to Louis XI., the adventure of the robber should have taken place before April 1462, the date of her first, and as it would seem her only, visit to him.

The third volume or book of Monstrelet follows Du Clereq in relating the incident in juxtaposition with events of 1463, unconnected with England, and begins thus."

"Icy convient bien dire l'adventure que la Royne d'Angleterre eust à celle fois avec le seigneur de Varenne."

The scene is laid in a forest in England, and the story is told down to "Sauve le fils de ton Roy." It proceeds, "Le brigant le print tout voulontiers et s'en allèrent, tellement que tost après ils vindrent par mer à l'Escluse et de l'Escluse s'en alla à Bruges," where she is honourably received by the Duke of Burgundy, referring, as Du Clercq does, to the known events of the Queen's second voyage in 1463.

a Monstrelet, ed. 1595, iii. 96 .

VOL. XLVII.

$2 \mathbf{R}$ 
The tale thus given by the pseudo-Monstrelet then concludes by repeating the statement of Du Clercq, that meanwhile her husband, the King Henry, was in Wales in one of the strongest places in England. The continuator of Monstrelet, it will be observed, leaves out the puzzling reference to the visit to King Louis. But he follows Du Clereq in his mention of Hexham field in May 1464.

The account in the third volume of Monstrelet in Johnes's translation ${ }^{a}$ follows the French version lastly abstracted, with the remarkable divergence that the forest is placed in Hainault, ${ }^{\mathrm{b}}$ and the Queen's address to the brigand is altered to suit the locality, for she says, "Save the son of a King," not of your King, which would be nonsense unless the robber was an Englishman.

The statement in the two French chronicles that Henry was at the time of the adventure in his castle in Wales, cannot, I think, be true, if it took place immediately before either voyage, in April 1462, that is, or in April 1463: for on the former occasion Henry seems almost certainly to have been in Scotland, and in 1463 the Queen, as before noticed, really sailed to Sluys from Bamborough, quite openly and with a large retinue, and her royal spouse was most likely in that fortress at the time.

He was certainly there in December 1463, when letters of protection for William Burgh were issued under his signet, and dated at Bamborough on the eighth of that month, in the forty-second year of his reign, ${ }^{c}$ and I see no good reason for his having meanwhile withdrawn himself into Wales.

The fact is, that the greater part of Miss Strickland's amplifications of the story-for brevity's sake I have omitted a good many of them-come from a life of Queen Margaret, written in the last century by the Abbé Prévost, best known as the author of Manon l'Escaut.

This biography is indeed a mere historical romance, in which an imaginary "Miladi Nevill" plays a great part. She is supposed to be a sister of the kingmaker, but certainly was no credit to the family, her manners being of the most free, and her virtue of the most easy sort. In her company another character appears, equally unknown to history, except, indeed, to that branch of it which

a Johnes's Monstrelet, ed. 1840, ii. 288.

b Miss Strickland seems to have nsed Johnes's translation, for she observes, no doubt correctly, that Hainault must be a blunder of a copyist for England. It is, I think, quite impossible that the Queen, either on her first or her second voyage, could have got into Hainault at all.

c The original letters are in the possession of Sir John Lawson of Burgh, Bart. and will be found printed in the Archceologia, XLVII. p. $\mathbf{1 9 0 .}$ 
is valued only in the nursery. "La Dame Trott" is certainly a singular apparition among the nobles and gentles of the English court.

The Abbé's account of the adventure, intercalated with a brief and fairly accurate narration of Henry VI.'s capture and carrying off to London, occupies no less than 26 octavo pages. It is amusing enough, but $I$ have no intention of transcribing it. ${ }^{2}$ He has borrowed the false date from Rapin, the skeleton of the adventure from "Monstrelet," and for all the detail he has drawn upon a most fertile imagination.

To his book, however, Miss Strickland is indebted for the antecedents of the robber (his gigantic stature seems to be her own invention), the charity of his wife, the passage to Kirkcudbright, the romantic escape from $\mathrm{Mr}$. Cork (a most impossible Englishman), the undignified landing "pick-a-back" at Cantyre, the name Barville assigned to the squire, and for everything else which is not in Monstrelet's or Du Clereq's brief narrative.

I have been unable to find the authority for Miss Strickland's "cave" near Hexham, where the robber dwelt. Prévost mentions the bandit's dwelling, but does not call it a cave.

Miss Strickland says that there is a local legend which assigns a cave in that neighbourhood as the scene of the adventure, and that no one who has minutely studied the antiquities of the town can doubt the fact, i.e. the truth of the legend, and gives a description of the so-called Queen Margaret's Cave.

The editors of the first part of vol. i. of Mr. Hodgson's History of Northumberland briefly notice (p. 328), in a very good resumé of the events so far as they relate to Northumberland, the existence of such a legend, but give no reference to any book for it, nor do I happen to have found any work giving the particulars. However circumstantial, it can have little historical value.

It is noteworthy that William of Wyrcestre (p. 481) says, that after the battle of Northampton, so far back as 1460, Queen Margaret with her son fled from Eccleshall towards Chester, and was nearly taken by one John Cleyer, a retainer of Lord Stanley, and was robbed of all her goods and jewels by her own servants; that she nevertheless got off in safety with her son to her castle, no doubt Harlech Castle. Gregory also (p. 208) narrates that, upon the Duke of York's entry into London (not long after the battle of Northampton), and laying claim to her Crown, Margaret "voydyde unto Walys, but she was met with be syde the Castelle of Malepas (in Cheshire, some thirty miles W.N.W. of Eccleshall), and a servand of hyr owne that she hadde made bothe yeman and gentylman, and aftyr

a Euvres choisies de l'Abbé Prévost. Amsterdam, 1784, tome xiv. pp. 207-233.

$2 \mathrm{R} 2$ 
apoynted for to be in office with hyr sone the prynce, spoylyde hyr and robbyde hyr, and put hyr soo in dowt of hyr lyffe and sonys lyffe also. And thenn she com to the Castelle of Hardelowe in Walys," \&c.

Now it is quite possible that the Queen may have "fallen among thieves" more than once in her eventful career, but I am not indisposed to believe that there was but one such adventure, and that, in the incident recorded by Wyrcestre and Gregory, we have the origin of the French, or rather Flemish, story, the details of which may however be quite true. ${ }^{a}$

I see no proof that Henry ever took shelter at Harlech, but the assertion in the two Flemish books that at the time of the adventure Henry was in a strong Welsh castle may well be a mistake grounded on the fact that the Queen after the robbery escaped thither.

Before leaving the robber story and concluding this paper, I will briefly examine the narratives of Rapin, Hume, Lingard, and Sharon Turner, as to these transactions.

Rapin's account is inexact. After mentioning Queen Margaret's descents on the northern coast in 1462 , he comes immediately to the advance of Lord Montagu and the battles of Hedgeley Moor and Hexham, which he treats but very briefly as the end of the same campaign. Having erroneously made Margaret advance into Northumberland after the storm at sea and retreat to Berwick, he supposes her to have been at Hexham and to have shared with her son the flight of Henry into Scotland. ${ }^{b}$ Having entirely omitted any mention of the first recapture of the castles, he rightly states that Warwick recovered them after Hexham, but wrongly notices the partial relief of Alnwick by the Scots as an incident of the final recapture.

Coming presently to Henry's being taken prisoner and confined in the Tower of London, ${ }^{\circ}$ he tells the adventure of the robber. He infers from it that

a Yet again, in the contemporary chronicle of Adrien de But (Belgian Doc. Inédits. 1870, p. 454), there is this brief notice of a robbery in connection with Margaret's second voyage in 1463:-

"Margarita regina Angliæ cum Edwardo parvulo filio, venit at curiam Ducis Philippi, qui fecit eam deduci ad Lotharingiam, sed in viâ deprædata fuit."

This seems rather to mean that it was on the journey to Lorraine that she was waylaid, and not before arrival at the ducal court. Can the adventure, after all, have happened in Hainault, as Mr. Johnes so unaccountably states? That province is not exactly out of the road from Bruges to Verdun.

b Rapin has been followed without suspicion by the compilers of L'Art de vérifier les Dates, vii. 149, ed. 1818.

c It is by no means clear whether he intends to place this event in 1463 or 1464; the real date being 1465 . 
Margaret had separated from her husband (whom rightly or wrongly he brings from Edinburgh into England immediately before his capture) and resolved also to hide in England until she could escape, observing that, if the adventure be true, it must have occurred about this time.

It need hardly be repeated that, although Margaret may possibly have been in Scotland at some time in 1463, she had departed for the Continent long before Hexham field.

As for Hume, he makes Louis XI. send de Brezé on an independent expedition resulting merely in the capture of Alnwick in 1462, prior to Margaret's visit to him. As the result of that visit and the promise to surrender Calais, he says that Louis was induced, as in 1464, "to send along with her a body of 2,000 men-at-arms, which enabled her to take the field and to make an inroad into England. Though reinforced by a numerous train of adventurers from Scotland and by many partisans of the family of Lancaster, she received a check at Hedgley Moor from Lord Montague, \&c." and then naturally Hexham follows.

The utter incorrectness of all this, except that Hume has the right date for the two battles, needs, it is to be hoped, no further exposure.

The robber adventure is told as occurring to the Queen after her supposed defeat at Hexham, while the pseudo Monstrelet is followed in his account of her subsequent concealment and escape to her father's court.

Lingard ${ }^{\mathrm{a}}$ states the sequence of events accurately, though somewhat jmperfectly, but his dates of years in which the events occurred are wrong.

He passes over the whole 1462 as if there was nothing to record, and comes to 1463. He refers to this year the whole of the events of 1462, month by month, beginning with Margaret's first voyage in April down to the retaking of Alnwick, dated in the margin Jan. 5, that is to say, January 5, 1.464. ${ }^{\mathrm{b}}$ But he is not consistent with himself, for at the top of the page, immediately over "Jan. 5," he has retained the running date 1463 , giving at first sight an appearance of accuracy.

a Page 145, seqq. 5th ed. 1849.

b The date of the Queen's landing in Bretagne is given in the margin as "1463 April 8," and as the first event of that year. This is no misprint for 1462, as is shown by the day of the month. This corresponds with Good Friday, 1463, and Lingard was evidently following William Wyrcestre, who says the landing in Brittany was on that fast-day, "Dies Parasceres," but somehow he has gone one year forward. Good Friday, 1462 (the real date) fell on April 16. Miss Strickland, p. 267, quotes Lingard for the landing in Brittany as on April 8, 1462. She has set right the year, but, failing to observe that the day of the month depended on Easter, has not altered 8 to 16 . 
He then tells the tale of the robber, as happening probably "in this winter campaign," and as the termination of it he gives Margaret's second voyage to Sluys. The marginal date of the month for this is "April," which, if governed by the running date 1463 , would be right, but the text unmistakably brings it to April 1464. On the next page the marginal date 1464 first occurs, and correctly, in conjunction with April 25, as the date of the battle of Hedgeley Moor.

Mr. Sharon Turner's account of this passage of history is very clear and painstaking. Having adopted the public records and the contemporary chronicles as his chief authorities, he has avoided many of the mistakes or confused statements of other writers. He has however missed the second capture of the three castles by the Iancastrians.

At p. 259 of his third volume, second edition, he has the following footnote as to the robber-story :

The incidents mentioned but not dated by Monstrelet, of the Queen's being plundered by robbers in her flight in a forest (\&c. \&c.), are usually connected with the battle of Hexham. But they rather suit the period mentioned before p. 256 (that is, the period before the Queen's second voyage). Monstrelet adds, that Henry at this time entered into Wales. Johnes has inserted " the forest of Hainault" in his translation, but the French of my edition of Monstrelet is " une forest en Angleterre."

Mr. Turner, whose work I did not look at until this paper was nearly complete, has here anticipated some of my remarks.

He agrees with me in adopting William of Worcester's (and Wassebourg's) statement that Margaret, after finding her way to Lorraine, "waited the issue of the course of things," and gives no hint of her return in the following year. 